\title{
Correction to: Effects of salinity on the growth and mucous cells of the abalone Haliotis diversicolor Reeve, 1846
}

\author{
Lota Alcantara Creencia • Tadahide Noro
}

Published online: 29 June 2018

(C) The Author(s) 2018

Correction to: Int Aquat Res

https://doi.org/10.1007/s40071-018-0199-0

The original version of this article unfortunately contained a mistake. The captions of Figs. 1 and 2 were swapped. The corrected Figs. 1 and 2 and captions are given below:

The original article can be found online at https://doi.org/10.1007/s40071-018-0199-0.

L. A. Creencia $(\bowtie)$

College of Fisheries and Aquatic Sciences, Western Philippines University, Sta. Monica, 5300 Puerto Princesa City, Philippines

e-mail: lotacreencia@gmail.com

L. A. Creencia - T. Noro

Faculty of Fisheries, Kagoshima University, 4-50-20 Shimoarata, Kagoshima 890-0056, Japan

e-mail: tadnoro@gmail.com

T. Noro

Kagoshima Prefectural College, 1-42-1 Shimo-ishiki, Kagoshima City 890-0005, Japan 

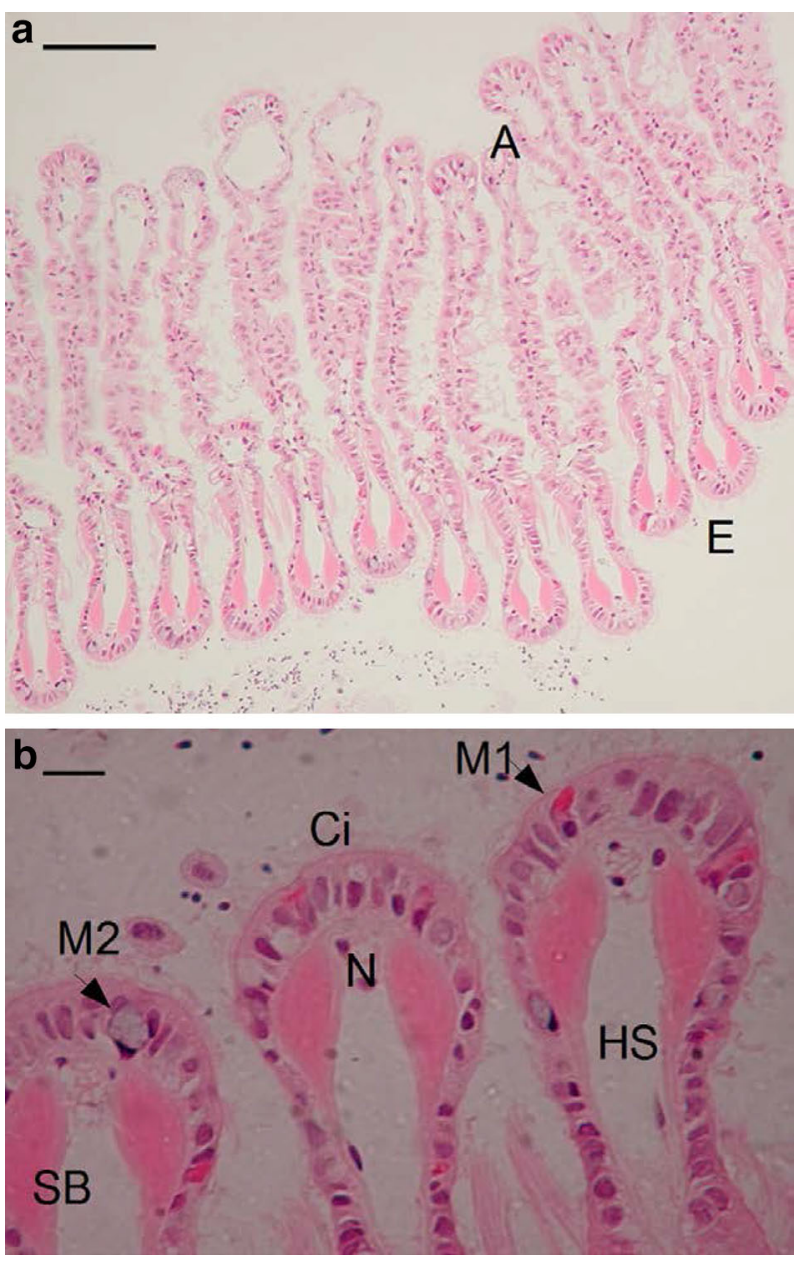

Fig. 1 Photomicrograph of the gill of $H$. diversicolor stained with $\mathrm{H}-\mathrm{E}$ : a longitudinal section of gill filaments showing the afferent end (A) and efferent end (E), scale bar $=100 \mu \mathrm{m}$; b enlarged efferent end showing mucous-1 (M1), mucous-2 (M2) and cilia $(\mathrm{Ci})$, hemocoelic space $(\mathrm{HS})$ and nerve $(\mathrm{N})$, bar $=10 \mu \mathrm{m}$ 

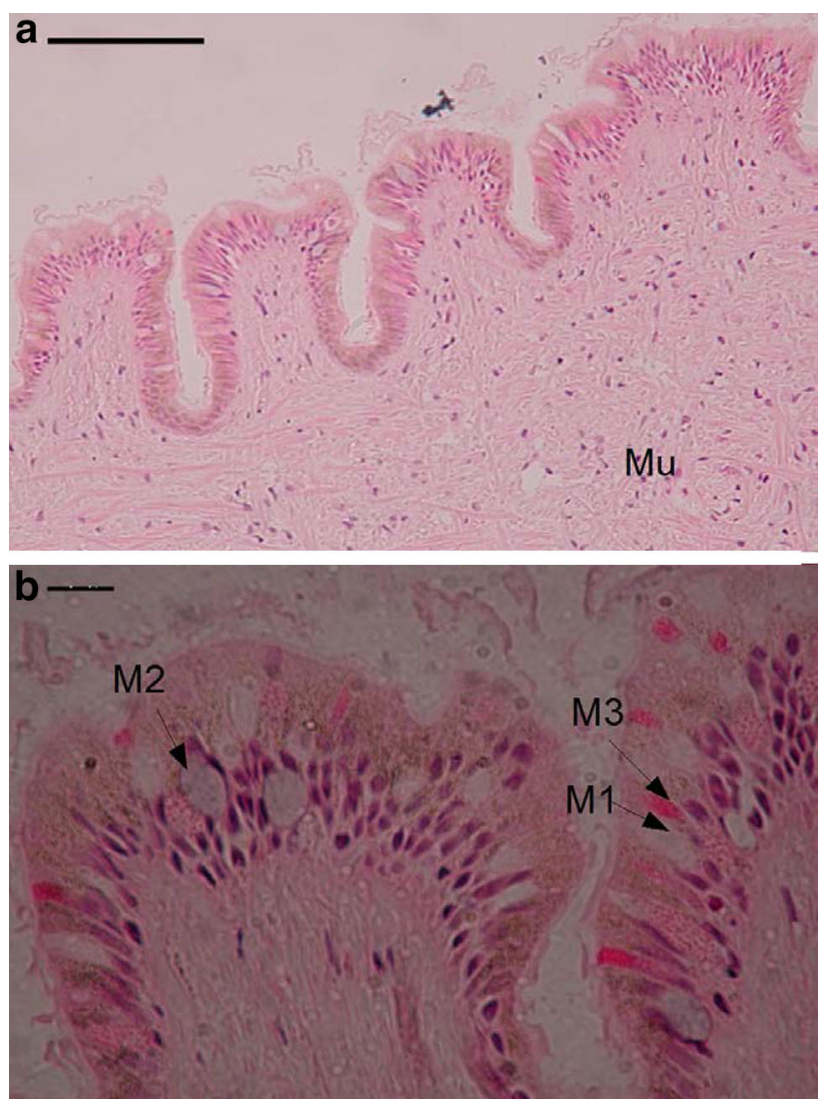

Fig. 2 Photomicrograph of the lip of $H$. diversicolor stained with Hematoxylin and Eosin: a longitudinal section of folds of epithelial cells and supporting muscle, scale bar $=100 \mu \mathrm{m} ; \mathbf{b}$ enlarged boxed fold showing mucous-1 (M1), mucous-2 (M2) and mucous-3 (M3), scale bar $=10 \mu \mathrm{m}$

Open Access This article is distributed under the terms of the Creative Commons Attribution 4.0 International License (http:// creativecommons.org/licenses/by/4.0/), which permits unrestricted use, distribution, and reproduction in any medium, provided you give appropriate credit to the original author(s) and the source, provide a link to the Creative Commons license, and indicate if changes were made.

Publisher's Note Springer Nature remains neutral with regard to jurisdictional claims in published maps and institutional affiliations. 